\title{
Sieve size influence in estimating biomass, abundance and diversity in samples of deep-sea macrobenthos
}

\author{
John D. Gage*, David J. Hughes, José L. Gonzalez Vecino \\ Scottish Association for Marine Science, Dunstaffnage Marine Laboratory, Oban PA34 4AD, United Kingdom
}

\begin{abstract}
A divergence in sieve size protocols for washing samples has arisen among shallow- and deep-sea benthic biologists, which now affects comparability across the 2 environments. This has come about as a result of a perception of smaller body size among deep-sea benthic organisms. Two box-core samples from $~ 1900 \mathrm{~m}$ depth were examined to see how different sieve size affects estimation of biomass, abundance and diversity of macrofauna in the deep sea. Expressed as cumulative retentions, the coarsest sieve (1 $\mathrm{mm}$ mesh) retained $94 \%$ of the biomass retained in the finest sieve $(0.25 \mathrm{~mm})$, confirming the expectation that rarer, large-sized individuals contribute most to biomass of macrobenthos. There were small increases when progressively finer sieves were used, but the rate of increase declined markedly from 0.425 to $0.25 \mathrm{~mm}$ mesh. Numbers of individual organisms increased through the series, with a marked increase from 0.5 to $0.425 \mathrm{~mm}$ mesh; numbers of species did not increase as rapidly, but showed a similarly high rate between 0.5 and $0.425 \mathrm{~mm}$ mesh. The proportions of the total biomass in coarser sieves, and the total number of specimens retained by the finest sieve were rather similar to those shown in previous studies of inshore and continental shelf benthos. However, the retention of deep-sea species by the $0.5 \mathrm{~mm}$ sieve $(86 \%)$ was about the same as the percentage of inshore species retained by the $1.0 \mathrm{~mm}$ sieve (at this sieve size only $54 \%$ of deepsea species were retained). Although the finer sieves in both shallow- and deep-sea samples include many postlarval stages, this differing response for species must reflect smaller size of some adult macrobenthos in the deep sea. The effect on diversity depended on index used, with Shannon's index increasing down to the $0.5 \mathrm{~mm}$ mesh, but showing a variable response in the finer sieves. This probably mostly reflects increased retention of small-sized juveniles of species already retained, causing increasing unevenness in species abundances with smaller sieve size, rather than addition of smallsized species not previously retained in coarser sieves. Expected numbers of species calculated by rarefaction seems much less affected, with the degree of overlap of rarefaction curves reflecting relative similarity in distribution of species abundances. Degree of overestimation (of expected number of species against number of individuals along the curve) is greatest for the $1 \mathrm{~mm}$ mesh, even if the end-points of the curve show decreasing disparity, from 1 to $0.25 \mathrm{~mm}$ mesh, in total retention of species as well as individuals. It is argued that, as would apply in shallow water, the great dependence of evenness on sieve size makes shifts in distribution of species abundances caused by disturbance more difficult to detect against the baseline, unless a sufficiently small sieve has been used. When sieve retention was separately considered for the major taxonomic groups of macrobenthos (Polychaeta, Peracarida, Mollusca), differing patterns in relation to sieve size were found in terms of abundance and species. No single group can therefore serve as a reliable proxy for the total macrobenthic assemblage.
\end{abstract}

KEY WORDS: Benthos $\cdot$ Macrobenthos $\cdot$ Sieve size $\cdot$ Size distribution $\cdot$ Biomass $\cdot$ Abundance $\cdot$ Species richness $\cdot$ Diversity $\cdot$ Evenness $\cdot$ Disturbance $\cdot$ Bio-assessment

Resale or republication not permitted without written consent of the publisher

\section{INTRODUCTION}

There is an increasing requirement for baseline survey and monitoring of deep-sea benthic communities for the purpose of environmental impact assessment. It is therefore becoming urgent to better understand the implications of sieve size, which, since the benchmark paper by Mare (1942), has been used to define size- 
based categories of the benthic community. Many authors have cautioned that the exact size limits might depend on habitat under consideration. If, for example, the macrobenthos is taken as those metazoan animals (mainly comprising polychaetes, crustaceans and molluscs) retained by a screen with $1 \times 1 \mathrm{~mm}$ apertures, this places many numerous small individuals of these taxa, especially polychaetes, in a group with organisms such as nematodes and harpacticoid copepods as part of the meiobenthos. Furthermore, a $1 \mathrm{~mm}$ sieve will miss the often very numerous newly settled and juvenile stages of species which, as adults, are retained on the sieve (Thorson 1966). That a mesh size $<1 \mathrm{~mm}$ provides considerably better quantification of benthic abundance, as well as of many smaller 'macrobenthic' species, has emerged in several investigations (e.g. Driscoll 1964, Rees 1984, Bishop \& Hartley 1986), so that a smaller sieve mesh (usually $0.5 \mathrm{~mm}$ ) has now become the generally adopted standard for macrofaunal sampling in coastal waters (Dybern et al. 1976, Vitellio \& Dinet 1979, Eleftheriou \& Holme 1984 and references cited therein).

Such practical implications were first demonstrated from inshore soft sediment in California (Reish 1959). His results clearly showed how sieve size affects estimation of biomass, abundance and species richness of the organisms normally included in the macrobenthos. Bachelet (1990) later demonstrated similar results in samples from 85 to $185 \mathrm{~m}$ depth on the continental shelf in the southern Bay of Biscay in the NE Atlantic. He also found that when polychaetes, crustaceans and bivalve molluscs are considered separately, they show differing response to sieve size.

The same philosophy justifying adoption of a $0.5 \mathrm{~mm}$ sieve in shallow water, in order to improve retention of 'macrofauna', has driven deep-sea benthic biologists to use even finer-meshed sieves than those applied in shallow water, in order to retain sufficient organisms for quantitative estimates. This is because of lower organism densities and the perceived smaller size of most species in the deep sea (Thiel 1975, Gage 1978, Gage \& Tyler 1991, Rex \& Etter 1998), a difference first documented quantitatively by Rowe \& Menzel (1971). A $0.42 \mathrm{~mm}$ sieve was adopted by H. L. Sanders for deep-water epibenthic sled sampling in the NW Atlantic in the 1960s (Sanders et al. 1965). Subsequently, a $0.297 \mathrm{~mm}$ sieve was used by R. R. Hessler for abyssal sampling in the central North Pacific (Hessler \& Jumars 1974). Hessler (1974) commented that in order to catch anything at all in such oligotrophic sediments a much finer-meshed sieve was essential, and furthermore that 'macrofaunal' taxa found there were of only meiofaunal size compared to shallow water; hence, a $1 \mathrm{~mm}$ sieve retained virtually no macrofauna at all. A $0.3 \mathrm{~mm}$ sieve was used by J. F. Grassle and his co-workers in their benchmark study of the US continental slope (Blake et al. 1987, Maciolek et al. $1987 \mathrm{a}, \mathrm{b})$. A $0.25 \mathrm{~mm}$ mesh is the standard used as the lower size limit for French studies of deep-water macrobenthos dating from the 1970s (Dinet et al. 1985). This sieve size has been adopted in subsequent EU-funded sampling programs in the abyssal deep sea, from the 1980s up to the time of writing.

The perceived need for a smaller sieve size has encouraged an argument for a more flexible definition of the division between macro- and meiobenthos based on taxonomic composition rather than size. In this taxonomic definition metazoan groups are included only if they will be sampled reasonably completely. This excludes traditionally 'meiobenthic' taxa such as nematodes, ostracods and copepods of which very few, if any, specimens will be retained, and which in any case will require a smaller sieve size in order to be collected adequately (Hessler \& Jumars 1974, Dinet et al. 1985). This differentiation based on 'macrobenthic' and 'meiobenthic' taxa now has wide acceptance from deep-sea biologists (Hessler \& Jumars 1974, Jumars \& Gallagher 1982, Rowe 1983). The macrobenthos defined in this way is termed the macrobenthos sensu stricto (excluding nematodes, copepods and ostracods) and the entire fraction (including any of the above 3 'meiobenthic' groups) retained by the $0.25 \mathrm{~mm}$ sieve as macrobenthos sensu lato (Dinet et al. 1985). Some recent studies on macrobenthos on the continental margin in the NE Atlantic have deviated from this by applying a $0.5 \mathrm{~mm}$ sieve. These studies include the 'Ocean Margin Exchanges Study' OMEX (Flach \& Heip 1996a,b, Flach \& Thomsen 1998, Flach et al. 1998, 1999, Flach \& de Bruin 1999) and the 'Atlantic Margin Environmental Surveys of the Seafloor' related to oilexploration and sponsored by the Atlantic Frontier Environmental Network AFEN (Atlantic Frontier Environmental Network 2000).

The purpose of the present study is to quantify the effect of different sieve sizes on commonly used summary indices of the deep-sea macrobenthic community. We used samples from a single bathyal site, at $1900 \mathrm{~m}$ depth in the Rockall Trough, to remove confounding effects of location and differences in depth; $1900 \mathrm{~m}$ is sufficiently deep to be distinct from the shelf environment, while lying within range of rapidly developing technology in hydrocarbon prospecting on the continental margin. Our study also examines relationships between sieve size and the different major faunal groupings of the macrobenthos by considering the polychaetes, peracarid crustaceans and molluscs separately.

In discussing the results, we consider how choice of sieve size relates to the size distributions of benthic organisms across all benthic marine environments, 
including the deep sea. We also compare the results with studies exploring relationships between body size, species abundance and diversity of marine benthic assemblages. The varying pattern from different indices of diversity applied to different sieve-size retentions can be explained in terms of their differing relative sensitivity to evenness and species richness.

\section{MATERIALS AND METHODS}

The 2 box-core samples (Stns SBC 792 and SBC 811, Table 1) were collected from $1900 \mathrm{~m}$ depth on the Feni Ridge, Rockall Trough, using a $0.25 \mathrm{~m}^{2}$ Mk II USNEL box-corer (see Gage \& Tyler 1991, p 48-50, Fig. 3.13) on 2 cruises of RRS 'Charles Darwin' during the Benthic Boundary Layer BENBO programme, funded by the UK Natural Environment Research Council. We were unable to process any more than 2 box-core samples, owing to the large amount of work entailed in standardisation and quantitatification of deep-sea samples to species level for 5 sieve sizes. Therefore it was not possible to apply a confidence interval to the estimates for each sieve size. The chosen depth is close to that targeted in a large-scale box-coring study undertaken in the NW Atlantic in the 1980s (Grassle \& Maciolek 1992). A high level of taxonomic quality control was applied to the latter study; assuming a comparable level was achieved in the present study, direct comparisons should be possible without having to make allowances for differing taxonomic resolution.

Samples were originally washed with filtered sea water, using the elutriation system (described by Sanders et al. 1965). A sieve of $30 \mathrm{~cm}$ diameter was used, with $0.25 \mathrm{~mm}$ square mesh of woven stainless steel wire. The retained material was fixed in sea water formalin and, after $3 \mathrm{~d}$, washed and transferred to $95 \%$ ethanol. In the laboratory the material was subsequently washed with tap water through a nest of coarser sieves $(1.0 \mathrm{~mm}, 0.5 \mathrm{~mm}, 0.425 \mathrm{~mm}, 0.3 \mathrm{~mm})$, with the material retained on each sieve then being sorted separately for macrobenthic taxa (all metazoan taxa excluding nematodes, copepods, ostracods and minor phyla normally considered part of the meiobenthos). For biomass estimation, the aggregated material from each box-core sample was blotted on filter paper and weighed using a top-loading balance. The samples were then sorted to major taxonomic groups and then to the level of putative or identified species by comparison, if necessary, against voucher specimens from a type collection of deep-sea macrobenthos held at the Dunstaffnage Marine Laboratory. The results are plotted as a cumulative retention to show the notional catch if each sieve had been used on its own. This treatment does not take into account any effect of
Table 1. Details of the two $0.25 \mathrm{~m}^{2}$ box-core samples

\begin{tabular}{|llll|}
\hline $\begin{array}{l}\text { Sample } \\
\text { designation }\end{array}$ & Date & Depth $(\mathrm{m})$ & Position \\
\hline SBC 792 & 13 May 1998 & 1889 & $57^{\circ} 08.57^{\prime} \mathrm{N}, 12^{\circ} 29.64^{\prime} \mathrm{W}$ \\
SBC 811 & 16 July 1998 & 1987 & $57^{\circ} 04.68^{\prime} \mathrm{N}, 12^{\circ} 27.22^{\prime} \mathrm{W}$ \\
\hline
\end{tabular}

retention of organisms resulting from re-sieving the picked sample after it had been fixed in formalin and preserved in alcohol, compared to the result had they been sieved on deck straight from the box-corer sampler using that screen size. Such differences might occur in samples from shallow water, where the movement or posture of living animals may affect the operation of the sieve. This would not normally occur with deep-sea samples because the animals are generally dead by the time they reach the surface. However, it is possible that there are very small differences in retention among fresh and fixed and alcohol-preserved samples arising from stiffening and possible shrinkage of the body.

Diversity statistics applied to the data generated in this study were calculated using the software package ${ }^{1}$ BioDiversity Professional Beta version 2, and follow definitions provided in Magurran (1988).

\section{RESULTS}

Wet weight biomass, numbers of individuals and species of deep-sea 'macrofaunal' organisms retained in sieves of different mesh size for each box-core sample is plotted graphically in Fig. 1. Values calculated from the 2 samples, pooled for the cumulative fractions, are summarised in Table 2 . The results show the dramatic effect of sieve size on faunal abundance and species richness in the 2 samples. However, these data also show that the coarsest sieve has already retained $94 \%$ of the biomass retention of the finest sieve. It should be noted that biomass, along with abundance, while continuing to increase, shows much smaller increments at sieve sizes below $0.425 \mathrm{~mm}$. Greatest rate of change in retention of individuals and species also occurs between the 0.5 and $0.425 \mathrm{~mm}$ sieve sizes (Fig. 1A,C). As might be expected, the most serious underestimation was by the $1.0 \mathrm{~mm}$ mesh, which retained only $19 \%$ of individuals and $54 \%$ of species collected by the $0.25 \mathrm{~mm}$ mesh (Table 2, Fig. 1B,C).

\footnotetext{
${ }^{1}$ McAleece N, Lambshead PJD, Paterson GLJ, Gage JD (1997) BioDiversity Professional, beta version 2. Software package produced by Natural History Museum, London and the Scottish Association for Marine Science, Oban, UK
} 

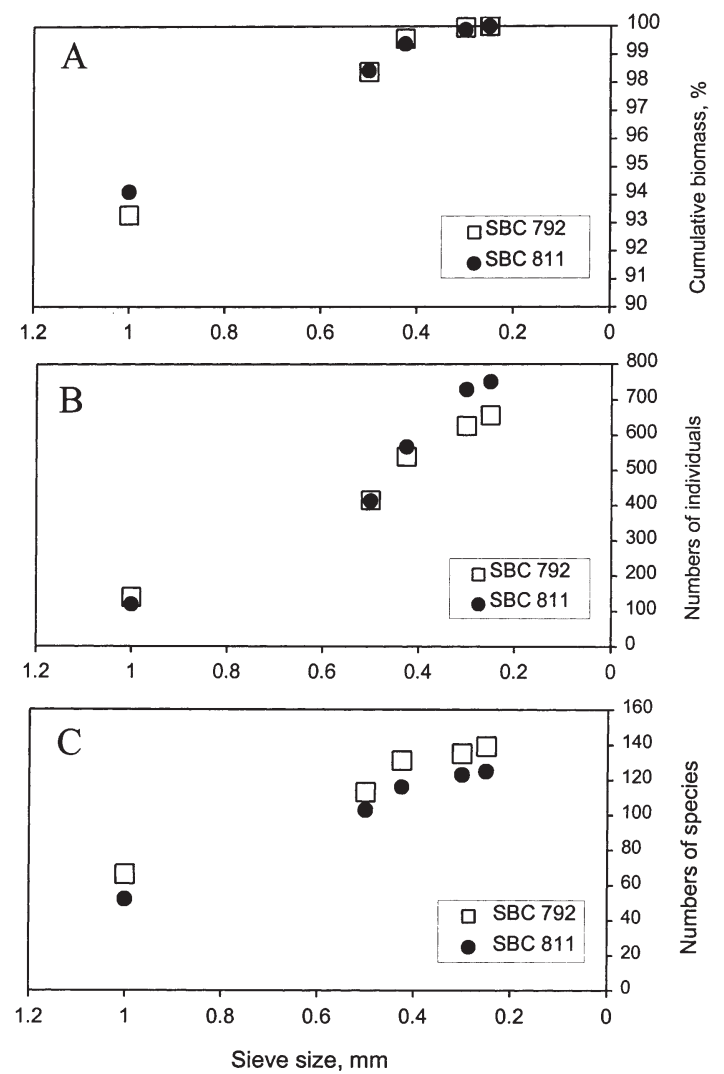

Fig. 1. Cumulative curves for retention of macrobenthos in sieves of decreasing mesh size: (A) total biomass (wet weight); (B) total no. of individuals; (C) total no. of species

Although use of a $0.5 \mathrm{~mm}$ sieve much improves retention, only $59 \%$ of individuals and $86 \%$ of species collected on the $0.25 \mathrm{~mm}$ sieve are retained (Table 2, Fig. 1B,C). The under-retention of species by the coarser sieves is significant because it shows that some of the smallest-sized species included in the 'taxonomic' definition of the macrobenthos are not being retained, resulting in underestimation of species richness.

Table 2. Diversity statistics applied to pooled data from box-core samples (total biomass, no. of individuals, no. of species) by sieve size

\begin{tabular}{|lccccc|}
\hline & \multicolumn{5}{c|}{ Sieve size (mesh, mm) } \\
Diversity index & 1.0 & 0.5 & 0.425 & 0.3 & 0.25 \\
\hline Shannon's $H^{\prime}(\log$ base 2$)$ & 5.71 & 5.83 & 5.85 & 5.85 & 5.89 \\
Pielou's $J^{\prime}$ & 0.87 & 0.81 & 0.79 & 0.79 & 0.79 \\
Simpson's diversity & 31.88 & 22.04 & 21.66 & 23.20 & 24.27 \\
index $(1 / D)$ & & & & & \\
Berger-Parker 1/d & 7.82 & 5.69 & 5.79 & 6.32 & 6.52 \\
$E\left(S_{258}\right)$ & 93 & 87.23 & 87.39 & 84.47 & 85.01 \\
Total biomass $\left(\mathrm{g} 0.5 \mathrm{~m}^{-2}\right)$ & 0.940 & 0.987 & 0.998 & 1.002 & 1.003 \\
Total $N\left(0.5 \mathrm{~m}^{-2}\right)$ & 258 & 820 & 1094 & 1334 & 1383 \\
Total $S\left(0.5 \mathrm{~m}^{-2}\right)$ & 93 & 149 & 165 & 169 & 173 \\
& & & & & \\
\hline
\end{tabular}

However, this is not reflected in estimates of species diversity (a concept incorporating both richness and the relative abundances of species). Table 2 summarises (by sieve size) values of diversity statistics, calculated from the pooled samples, that are commonly applied to estimate community characteristics of macrobenthic samples; these include Shannon's index of species diversity $H^{\prime}$ (also known as the ShannonWiener index). Table 2 also lists values for Simpson's index $D$, (usually expressed as the reciprocal $1 / D$, so that increasing diversity is expressed by increasing values). Values for Shannon's index drop sharply between 1.0 and $0.5 \mathrm{~mm}$ mesh, but remain roughly constant through the smallest sieves, while values for Simpson's index peak not at the $1 \mathrm{~mm}$ sieve size but between 0.5 and $0.425 \mathrm{~mm}$. Although apparently contradictory, an explanation lies in the differing sensitivity of the 2 indices to evenness in the assemblage, with Simpson's index being heavily weighted towards the most common species while being less sensitive to species richness, and hence rare species present, than Shannon's index. Two other statistics are commonly used to express the degree of dominance, or relative evenness, in species' abundances. These are Pielou's $J$ and the Berger-Parker index $d$ (expressed as the reciprocal 1/d). The use of Hill's numbers (Hill 1973) provides a unifying notation between different diversity indices, and a means for understanding their differing weighting given to rare species. This was achieved in terms of Hill's definition of a diversity index as 'the reciprocal mean proportional abundance' (for details see Magurran 1988, Soertaert \& Heip 1990). The Berger-Parker $d$ is closely related to one end member of Hill's numbers, in terms of the weighting given by each diversity index to rare species diversity. This is expressed as the reciprocal of the proportional abundance of the commonest species. The other end member is equivalent to the number of species in the assemblage $S$. Both Shannon's and Simpson's index occupy intermediate positions in Hill's classification.

Rarefaction (Sanders 1968, as modified by Hurlbert 1971) provides values of the expected number of species $E\left(S_{\mathrm{n}}\right)$ for varying sample size $\mathrm{n}$ up to the number of individuals in the whole sample $N$. Values of $E\left(S_{\mathrm{n}}\right)$ for the largest common number of individuals available from the sieve retentions $(\mathrm{n}=$ 258) show a much more conservative response to sieve size than that shown by Shannon's index. This is also evident from the rarefaction curves plotted for each sieve size (Fig. 2A), where $E\left(S_{258}\right)$ can be directly read off the 
$y$-axis from $\mathrm{n}=258$ on the $x$-axis. The small drop in value of $E\left(S_{258}\right)$ can be related to the differing degree of curvature of the rarefaction curves (Fig. 2A). As shown by Gage \& May (1994), curve flexure is determined by sample evenness. The curve for $1.0 \mathrm{~mm}$ is most flexed, so it provides an estimate for $E\left(S_{258}\right)$, or any lesser value of $\mathrm{n}$, slightly higher than from the next curve $(0.5 \mathrm{~mm})$, and this in turn will be higher than that from the rarefaction curves for the other sieve sizes. Furthermore, the sequence in curvature of the rarefactions (Fig. 2A) is mirrored by the sequence in skewness in distribution of species' abundances for these sieve sizes (Fig. 2B). The latter show a pattern of increasing dominance by the most common species (expressed as a left-hand skew in the ranked distribution of species' abundances) as the juvenile component of their population become increasingly retained by the smaller sieves. The degree of overestimation of expected number of species against number of individuals along the curve is greatest for the $1 \mathrm{~mm}$ sieve, even if the curve end-points show the decreasing disparity, from 1 to $0.25 \mathrm{~mm}$, in total retention of species as well as individuals.

Plots of percentage cumulative abundance against log species rank (Fig. 3), the $k$-dominance curves of Lambshead et al. (1984) and Platt et al. (1984), are essentially the inverse of the plots of ranked species abundances shown in Fig. 2B, but show cumulative abundance on a percent scale against the log species rank. Another way of looking at $k$-dominance is not just as the relative dominance of the most abundant species, as measured by the Berger-Parker index, but as a plot of the combined dominance of the 2 most abundant species, the 3 most abundant and so on up to the $k$ th species. Like those for ranked species abundance, the curves in Fig. 3 are rather similar for the different sieve retentions, except that for the $1 \mathrm{~mm}$ retention. This starts lower (reflecting much lower dominance by the most common species), but finishes higher by crossing over the rest. Magurran (1988) argues that such intersects are informative in that they illustrate the shift of dominance relative to that of species richness, with the crossing curve in this case showing how $k$-dominance becomes higher for the $1 \mathrm{~mm}$ retention than the rest at a relatively high value of $k$.

Table 3 shows values for each of the 3 major taxonomic components of the macrobenthos (Polychaeta, Peracrida, Mollusca) for the same single-figure indices of diversity applied to the pooled samples. Polychaetes contributed $62 \%$ of individuals and $36 \%$ of species, peracarid crustaceans $27 \%$ of individuals and $47 \%$ of species, and molluscs $10 \%$ of individuals and $15 \%$ of species. As might be expected from the relative percentages of individuals and species for each component, the polychaetes showed the largest numbers of
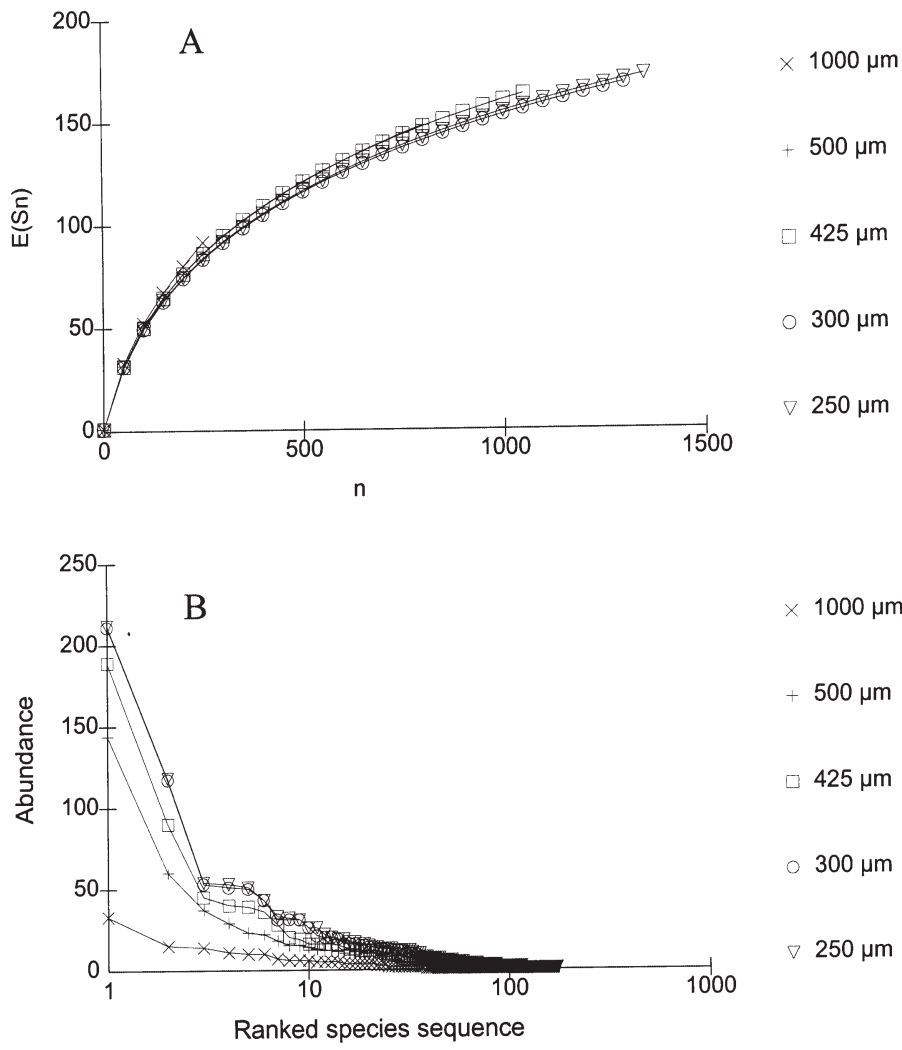

Fig. 2. (A) Rarefaction, and (B) ranked species abundance, from the pooled cumulative retentions in decreasing sieve sizes

individuals at all sieve sizes. All taxa increased in numbers with smaller sieve size. However, the molluscs from a similar starting point to peracarids in the $1 \mathrm{~mm}$ sieve showed a much lower rate of increase in abundance than the rest. There was a constant, low rate of increment in species for the peracarids and molluscs, but a faster rate for the polychaetes, especially between the 0.5 and $0.425 \mathrm{~mm}$ sieve sizes.

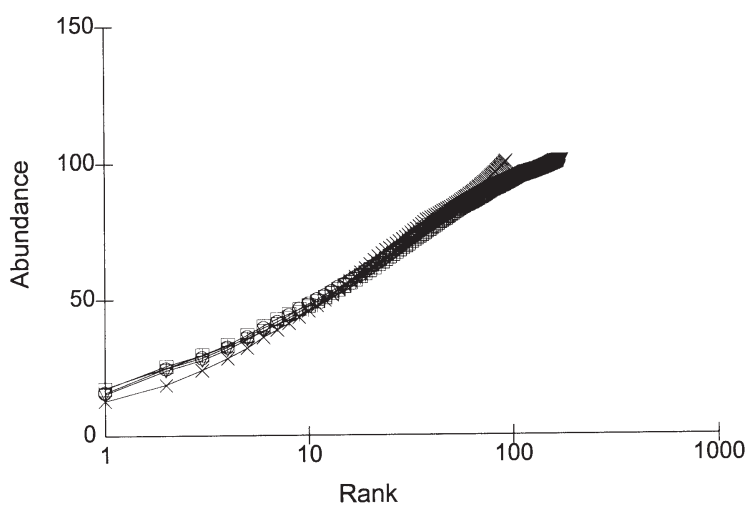

Fig. 3. $k$-dominance curves for the pooled data for different sieve sizes. Symbols as in Fig. 2 
Table 3. Diversity statistics applied to pooled data from box-core samples (total biomass, no. of individuals, no. of species) by sieve size, considering 3 major taxonomic groupings of macrobenthos separately

\begin{tabular}{|c|c|c|c|c|c|}
\hline \multirow[b]{2}{*}{ Diversity index } & \multicolumn{5}{|c|}{ Sieve size (mesh, mm) } \\
\hline & 1 & 0.5 & 0.425 & 0.3 & 0.25 \\
\hline \multicolumn{6}{|l|}{ Polychaetes only } \\
\hline Shannon $H^{\prime}$ (log base 2) & 4.761 & 4.439 & 4.351 & 4.306 & 4.304 \\
\hline Pielou's $J^{\prime}$ & 0.857 & 0.761 & 0.734 & 0.723 & 0.723 \\
\hline $\begin{array}{l}\text { Simpson's diversity } \\
\text { index }(1 / D)\end{array}$ & 18.617 & 10.765 & 10.201 & 10.186 & 10.199 \\
\hline Berger-Parker, $1 / d$ & 5.909 & 3.91 & 3.899 & 4.052 & 4.066 \\
\hline$E\left(S_{195}\right)$ & 47 & 39.72 & 38.16 & 37.01 & 36.93 \\
\hline Total $N\left(0.5 \mathrm{~m}^{2}\right)$ & 195 & 563 & 737 & 855 & 862 \\
\hline Total $S\left(0.5 \mathrm{~m}^{2}\right)$ & 47 & 57 & 61 & 62 & 62 \\
\hline Peracarids only & 1 & 0.5 & 0.425 & 0.3 & 0.25 \\
\hline Shannon $H^{\prime}$ (log base 2) & 4.75 & 5.472 & 5.651 & 5.476 & 5.485 \\
\hline Pielou's $J^{\prime}$ & 0.988 & 0.923 & 0.907 & 0.871 & 0.863 \\
\hline $\begin{array}{l}\text { Simpson's diversity } \\
\text { index }(1 / D)\end{array}$ & 124 & 42.84 & 42.629 & 30.971 & 30.343 \\
\hline Berger-Parker, $1 / d$ & 16 & 14.909 & 15.688 & 11.129 & 11.242 \\
\hline$E(S 131)$ & 27.25 & 22.89 & 23 & 21.45 & 21.31 \\
\hline Total $N\left(0.5 \mathrm{~m}^{2}\right)$ & 32 & 164 & 251 & 345 & 371 \\
\hline Total $S\left(0.5 \mathrm{~m}^{2}\right)$ & 28 & 61 & 75 & 78 & 82 \\
\hline Molluscs only & 1 & 0.5 & 0.425 & 0.3 & 0.25 \\
\hline Shannon $H^{\prime}$ (log base 2) & 3.594 & 4.074 & 4.14 & 4.015 & 4.012 \\
\hline Pielou's $J^{\prime}$ & 0.944 & 0.877 & 0.891 & 0.854 & 0.844 \\
\hline $\begin{array}{l}\text { Simpson's diversity } \\
\text { index }(1 / D)\end{array}$ & 17.105 & 15.357 & 15.963 & 13.099 & 12.833 \\
\hline Berger-Parker, $1 / d$ & 6.5 & 7 & 7.154 & 5.667 & 6.045 \\
\hline$E(S 25)$ & 13.73 & 13.67 & 14.03 & 13.06 & 12.92 \\
\hline Total $N\left(0.5 \mathrm{~m}^{-2}\right)$ & 26 & 83 & 93 & 119 & 133 \\
\hline Total $S\left(0.5 \mathrm{~m}^{-2}\right)$ & 14 & 25 & 25 & 26 & 26 \\
\hline
\end{tabular}

to habitat considered and methods employed. She recognised that the characteristic taxa of each group may well have a size range whose tails extend beyond the lower and upper size limits determined by the sieves used. Dahl et al. (1976) judged that the convenience of retaining the same size limits was more important than adapting to a shift in taxonomic composition caused, for example, by a decrease in body size in the deep sea. This is echoed by Thiel (1983) who, although well aware of body size miniaturisation of 'macrobenthic' taxa, maintained that benthos size groups should be purely defined by size. This view (as adopted in SCOR Working Group 76, 1994) is supported by the quantitative distribution in organism size, and associated functional and metabolic differentiation (Banse \& Mosher 1980, Schwinghamer 1981, 1983, Banse 1982, Warwick 1984, Gerlach et al. 1985), even if the expression of size-based discontinuity varies somewhat in different environments (Warwick 1984, Schwinghamer 1985, Drgas et al. 1998, Duplisea \& Drgas 1999).

Biomass retention agrees rather well with the inshore data of Reish (1959), where $95 \%$ of biomass was retained by

Values of the diversity indices Shannon's $H^{\prime}$ and $E\left(S_{\mathrm{n}}\right)$ calculated for the relatively low value of $\mathrm{n}=25$ show a varying pattern, with diversity decreasing slightly with decreasing sieve size for $H^{\prime}$ (peracarids only) and for $E\left(S_{25}\right)$ for all 3 groups. The pattern for Simpson's index, a measure of diversity heavily weighted towards dominance, shows for the polychaetes an almost mirror image of the curve for species richness, while those for the other taxa are virtually flat, but at a lower level. The Berger-Parker index also shows the greatest variability for the polychaetes, with evenness declining but showing a small increase for the $0.425 \mathrm{~mm}$ mesh. Change in the pattern for the other 2 groups was somewhat small, although both showed a considerably lower level of evenness than showed by polychaetes.

\section{DISCUSSION}

\section{Which definition to use?}

Mare (1942) noted that the exact limits of the micro-, meio- and macrobenthos would probably vary according the $1.0 \mathrm{~mm}$ mesh, compared to $94 \%$ in the present study (Table 2). Hence, the data are consistent with the view, long known in shallow water, that biomass tends to be largely determined by the presence of relatively rare large-sized specimens. Relative retention of individuals by a $0.5 \mathrm{~mm}$ sieve size compared to what would have been retained by a $0.25 \mathrm{~mm}$ mesh, $86 \%$ in the present samples (Table 2), is broadly similar to the proportion retained for subtidal samples, as read from plotted data in Reish (1959) and Bachelet (1990). For species, however, there is wide divergence in sieve retention. While only $86 \%$ of deep-sea species were retained by the $0.5 \mathrm{~mm}$ mesh (Table 2, Fig. 1C), in shallow subtidal communities the $0.5 \mathrm{~mm}$ mesh adds few species to the faunal list established from the $1.0 \mathrm{~mm}$ mesh (Bachelet 1990 and references therein.) This compares with a retention in the $1.0 \mathrm{~mm}$ mesh of only $54 \%$ of the total recorded from the $0.25 \mathrm{~mm}$ mesh in the present samples from the deep sea.

The relative proportion of species recorded only as small, pre-adult sizes is unknown, but it seems unlikely that there would be more of these in the deep sea than in shallow water, even if the proportion of larval stages present might be expected to be quite high 
at certain times of the year. Bachelet (1990) demonstrated that substantial seasonal change in retention may occur as a result of recruitment of juveniles. Even if the shallow-water sampling coincided with such a period, one might expect adult sizes also to be present, even if at lower density. Whatever the cause, the difference is consistent there being smaller macrobenthic organisms in the deep sea than in coastal macrobenthos. Hence, the taxonomically based separation has the advantage of keeping taxonomic entities together, even when size as juveniles (as would apply to a large number of individuals $<0.5 \mathrm{~mm}$ in this study) may place them in the next lower category.

Which argument becomes most important clearly depends on the particular aims of the study. They may relate best to functional adaptation determining either a 'meio-' or 'macrobenthic' mode of life. In terms of sensitivities to contaminants or physical disturbance, such traits determining broad life history characteristics may be more important than precise taxonomic composition. Alternatively, study aims may be more relevant to taxonomic composition (i.e. the division based on 'meio-' or 'macrobenthic' taxa), for instance when particular taxon-specific characteristics are compared across depth. For example, Olsgard et al. (1998) suggest that the response to stress may be more similar when considered by higher taxonomic groupings than by size class or functional group.

Practical issues of comparability with other studies are also important in order to allow easier interpretation of the data. Even if the first argument is important then unless sampling specifically targeting the meiobenthos peak is also undertaken, a finer mesh will retain more 'macrobenthic' organisms from the deep sea than a $0.5 \mathrm{~mm}$ mesh. If comparability is important, perhaps the issue is whether deep-sea samples should only be compared with other studies from the deep sea, or also with those from shallow water. If the former option is chosen, then this closes the door on potentially rewarding comparisons encompassing both shallow and deep sea.

\section{Sieve size in relation to estimating species richness, diversity and evenness}

In coastal benthos, measurable parameters such as the species richness and evenness in species abundances have been regarded as sensitive indicators of community disturbance, or stress, e.g. that caused by low-level pollution (Gray \& Mirza 1979, Ugland \& Gray 1982). The degree of evenness, or relative dominance, in species' abundances in particular is considered a useful and sensitive indicator of disturbance in marine benthic communities (Lambshead et al. 1983, Shaw et al. 1983).
The sharply declining degree to which a sample is dominated by the most common species with increasing sieve size is best shown in the plot of ranked abundances for the pooled samples (Fig. 2B). The relatively flat distribution from the $1.0 \mathrm{~mm}$ mesh sample shows that abundances of the most common species are little more than those of rare species. Observations during sorting of the BENBO samples suggest that this is caused largely by retention of young stages otherwise lost with coarse-meshed sieves. However, the clarity of this pattern from the single-figure indices most sensitive to dominance was not encouraging. Both Pielou's $J$ and the Berger-Parker index show a variable pattern for the 2 box-core samples (Table 2). Furthermore, Table 2 shows highest values for the pooled sample in the middle sieve sizes, in response to the abundance of just 1 species, a glycerid polychaete, whose minimum body size in the population led to it being nearly all retained in the 0.5 and $0.425 \mathrm{~mm}$ sieves. Such differences among taxa, in the minimum body size in populations, will likely introduce considerable variability in the pattern in relation to sieve size.

Nevertheless, shifts in size structure of the community towards a predominance of smaller sized species, with a larger proportion of juveniles, is recognised as characteristic of disturbance in benthic communities (Grassle \& Sanders 1973, Pearson \& Rosenberg 1978, Gray 1989). The low-diversity, high-dominance benthic assemblage described for the hydrodynamically disturbed HEBBLE site, on the continental rise in the NW Atlantic, was largely composed of sub-adults (Thistle et al. 1985). Clearly, to best detect such disturbance-related changes in size structure, the smallest practicable sieve size necessary to retain the smallest elements of the population should be used, a consideration that applies to both shallow and deep-sea environments. The marked dependence of evenness on sieve-size in deep-sea samples may, for the purpose of impact assessment, make shifts in distribution of species abundances caused by disturbance more difficult to detect against the baseline, unless a sufficiently small sieve size has been used.

However, seasonal breeding patterns causing variability among these smallest sizes may also need to be taken into account. In shallow water this may result in a seasonal pattern in numbers of individuals retained in the smallest sieve sizes that will vary year-round reflecting seasonal settlement patterns (Grassle et al. 1985, Bachelet 1990). Furthermore, Bachelet (1990) showed how this seasonal variability affected species richness, and indices of diversity and evenness. Seasonality in reproduction and settlement is known to occur among deep-sea benthos (Tyler 1988), and this may generate quite large-scale settlement at certain times of the year in certain species (e.g. Gage \& Tyler 
1981), or in colonisation of seasonally available phytodetrital material (e.g. Gooday 1988). However, diversity among large numbers of deep-sea macrobenthos in box-core samples taken at different times of the year on the continental slope off New England changed very little through time (Grassle \& Maciolek 1992).

\section{Sieve size and the importance of rare species}

As distinct from species richness (i.e. the number of species present) the sometimes large proportion of rare species present has been recognised in its own right as an important characteristic of some communities (Magurran 1988). Cao et al. (1998) show how the number of rare species present is influenced by disturbance, arguing that detection of rare species is important in determining the reliability and sensitivity of methods used in community analysis and bio-assessment. Subtle differences in rare species have been claimed to represent an initial effect of disturbance on macrobenthic communities (Gray et al. 1990). In a sampling or sample processing strategy, deletion of rare species will therefore have a differing effect depending on disturbance, with those least disturbed being most affected by sieve and sample size (Cao et al. 1998). This means that the sensitivity of statistics measuring evenness in species abundances is also much reduced. This may explain why evenness, measured as Pielou's $J^{\prime}$, and the Berger-Parker index 1/d, drops between $1 \mathrm{~mm}$ and $0.5 \mathrm{~mm}$, but thereafter either declines more slowly or remains roughly level with decreasing sieve size (Table 2). A similar trend for $J^{\prime}$ was demonstrated by Bachelet (1990) from intertidal samples.

The deep sea is thought to be characterised by a very large number of rare species in the 'macrobenthic' community, with samples typically being composed of large numbers of species occurring as singletons or in low numbers (Grassle \& Maciolek 1992). Whether or not the consequent interpretation of rareness is simply based on this, or refined to consideration of frequency of occurrence of a species in samples taken over a larger area, may need clarification for this habitat (Carney 1997). Nevertheless, methodology, such as too coarse a mesh size, that effectively removes rare species may decrease sensitivity in statistics applied to detect stress. Subtle qualitative differences in the presence of rare species are claimed to represent an even more sensitive initial effect of disturbance on benthic communities, at least in shallow water (Gray et al. 1990). Because rare species may also be more at risk of extinction, possible needs for conservation may have also been concealed.

It is clear from the data in the present study that use of a $0.5 \mathrm{~mm}$ mesh on its own may miss a number of the species collected on $0.425,0.3$ or $0.25 \mathrm{~mm}$ sieve sizes. Just as in coastal waters, many of the large numbers of individuals of small 'macrobenthic' taxa escaping the $0.5 \mathrm{~mm}$ sieve are juveniles, which are only transient members of the smaller size class. Most of these would be expected to be collected as adults in coarser sieves. Therefore a large proportion of the additional species retained by the $0.425,0.3$ and $0.25 \mathrm{~mm}$ mesh must belong to taxa normally thought to be part of the 'macrobenthos' that have not already been retained by the 1.0 and $0.5 \mathrm{~mm}$ mesh. Any under-retention of species is significant because this indicates that some of the smallest-sized species included in the 'taxonomic' definition of macrobenthos may not be retained by that sieve, resulting in underestimation of macrobenthic species richness. As was found by Bachelet (1990) from intertidal samples, values of the Shannon diversity statistic $H^{\prime}$ increase sharply between 1.0 and $0.5 \mathrm{~mm}$ sieve size (Table 2), but remain roughly constant from the $0.5 \mathrm{~mm}$ mesh through the smaller sieves. In terms of this statistic, the scale of under-estimation appears small; but the formulation of the Shannon statistic makes it insensitive to increasing numbers of rare species compared to rarefaction, which will more directly reflect species richness (Soetaert \& Heip 1990).

The underlying cause for this sieve-size related pattern of species richness in relation to total abundance can be explained in terms of empirical relationships between body size, species abundance and diversity among shallow-water macrobenthos, described by Warwick \& Clark (1996). Along with the expectation from meio- and macrobenthic size spectra (Schwinghamer 1981, Warwick 1984) of peaks in the distribution of species' size, Warwick \& Clark (1996) found abundances to peak at the same intermediate species' size. Whatever the cause for this, Warwick \& Clark (1996) argue that in practical terms this will cause more macrobenthic species to be retained for a given number of individuals on the coarser sieve compared to the next one down. This is because the coarsest sieve $(1.0 \mathrm{~mm})$ corresponds to the size at which smaller individuals of 'macrobenthic' species start to become lost, with use of a progressively finer sieve increasingly eliminating this effect. As a result of this, Warwick \& Clark (1996) predicted that comparisons of diversity are likely to be dependent on both sieve size and the size distribution of organisms present.

\section{Conclusions regarding bio-assessment}

Leaving aside issues of comparability with previous studies, for the purpose of describing macrobenthic biomass in the deep sea (but not abundance and species richness), a sieve as coarse as 1.0 or $0.5 \mathrm{~mm}$ might 
be used, depending on the precision required; sieve sizes smaller than $0.5 \mathrm{~mm}$ add very little to the estimate. Although, just as in coastal macrobenthos, additional numbers of individuals appear as more and more juvenile stages are collected in progressively finermeshed sieves, in the deep sea these numbers also include small-sized species that have passed through the coarser mesh. Although greatest accuracy in estimation will be achieved by using a $0.25 \mathrm{~mm}$ sieve, the difference over a $0.3 \mathrm{~mm}$ sieve, particularly for species counts, is measurable but very small.

From the results of the 2 deep-sea box-cores, we confirm the prediction by Warwick \& Clark (1996) of the likely dependency of diversity estimates on sieve size. However, this seemed to depend on the particular index applied, because of the varying influence of dominant and rare species. Hence, although species richness increases with use of finer sieves, estimates of species diversity usually increased from 1.0 to $0.5 \mathrm{~mm}$ sieve size but thereafter were varying or roughly stable, depending on relative sensitivity to rare species. Evenness dropped most between 1.0 and $0.5 \mathrm{~mm}$ mesh and thereafter dropped slightly or was roughly stable in smaller sieve sizes, depending on index. In view of this it is important that comparisons employ the same sieve size and diversity index in relation to considerations of minimum sample size (see Soertaert \& Heip 1990).

Polychaetes, peracarids and molluscs show different responses to sieve size, when considered separately. It may therefore be unwise to assume that the results from 1 group can be taken as a proxy for the total assemblage.

The relatively great dependence of evenness on sieve-size in deep-sea samples may, for the purpose of bio-assessment, make shifts in the distribution of species abundances (caused by disturbance) more difficult to detect against the baseline unless a sufficiently small sieve has been used. In these circumstances, the smallest practicable sieve necessary to retain juveniles should be used.

Acknowledgements. We thank Kirsten Kroeger and Peter Lamont for their assistance with sample collection and sorting. The work was funded by research grant GST/02/2080 awarded to the first author as part of a thematic programme on the benthic boundary layer (BENBO) funded by the U.K. Natural Environment Research Council.

\section{LITERATURE CITED}

Atlantic Frontier Environmental Network (2000) Atlantic margin environmental surveys of the seafloor 1996 \& 1998. CD-ROM available from Geotek Ltd, Daventry, Northamptonshire, UK

Bachelet G (1990) The choice of a sieving mesh size in the quantitative assessment of marine macrobenthos: a necessary compromise between aims and constraints. Mar Environ Res 30:21-35

Banse K (1982) Mass-scaled rates of respiration and intrinsic growth in very small invertebrates. Mar Ecol Prog Ser 9: 281-297

Banse K, Mosher S (1980) Adult body mass and annual production/biomass relationships of field populations. Ecol Monogr 50:355-379

Bishop JDD, Hartley JP (1986) A comparison of the fauna retained on 0.5 and $1.0 \mathrm{~mm}$ meshes from benthic samples taken in the Beatrice Oilfield, Moray Firth, Scotland. Proc R Soc Edinb Sect B (Biol Sci) 91:247-262

Blake JA, Hecker B, Grassle JF, Brown B and 9 others (1987) Study of biological processes on the US South Atlantic slope and rise. Phase 2. Final report prepared for US Department of the Interior, Minerals Management Service, Washington, DC

Cao Y, Williams DD, Williams NE (1998) How important are rare species in aquatic community ecology and bioassessment? Limnol Oceanogr 43:1403-1409

Carney RS (1997) Basing conservation policies for the deepsea floor on current diversity concepts: a consideration of rarity. Biodivers Conserv 6:1463-1485

Dahl E, Laubier L, Sibuet M, Stromberg JO (1976) Some quantitative results on benthic communities of the deep Norwegian Sea. Astarte 9:61-79

Dinet A, Desbruyères D, Khripounoff A (1985) Abondance des peuplement macro- et méiobenthiques: répartition et stratégie d'échantillonage. In: Laubier L, Monniot C (eds) Peuplements profonds du Golfe de Gascogne: campagnes Biogas. IFREMER, Brest, p 121-142

Drgas A, Radziejewska T, Warzocha J (1998) Biomass size spectra of near-shore shallow-water benthic communities in the Gulf of Gdansk (southern Baltic Sea). Mar Ecol 19: 209-228

Driscoll AL (1964) Relationship of mesh opening to faunal counts in a quantitative benthic study of Hadley Harbor. Biol Bull 127:368

Duplisea DE, Drgas A (1999) Sensitivity of a benthic, metazoan, biomass size spectrum to differences in sediment granulometry. Mar Ecol Prog Ser 177:73-81

Dybern BI, Ackefors H, Elmgren R (eds) (1976) Recommendations on methods for marine biological studies in the Baltic. Publication No. 1, Baltic Marine Biologists, Stockholm

Eleftheriou A, Holme NA (1984) Macrofauna techniques. In: NA Holme NA, Eleftheriou T (eds) Methods for the study of marine benthos, Blackwell Scientific Publications, Oxford, p 140-216

Flach E, Heip C (1996a) Seasonal variations in faunal distribution and activity across the continental slope of the Goban Spur area (NE Atlantic). J Sea Res 36:203-215

Flach E, Heip C (1996b) Vertical distribution of macrozoobenthos within the sediment on the continental slope of the Goban Spur area (NE Atlantic). Mar Ecol Prog Ser 141: $55-66$

Flach E, Thomsen L (1998) Do physical and chemical factors structure the macrobenthic community at a continental slope in the NE Atlantic? Hydrobiologia 375/376:265-285

Flach E, de Bruin W (1999) Diversity patterns in macrobenthos across a continental slope in the NE Atlantic. J Sea Res 42:303-323

Flach E, Lavaleye M, de Stiger H, Thomsen L (1998) Feeding types of the benthic community and particle transport across the slope of the NW European continental margin (Goban Spur). Prog Oceanog 42:209-231 
Flach E, Vanaverbeke J, Heip C (1999) The meiofauna: macrofauna ratio across the continental slope of the Goban Spur (north-east Atlantic). J Mar Biol Assoc UK 79:233-241

Gage JD (1978) Animals in deep sea sediments. Proc R Soc Edinb Sect B (Biol Sci) 76:77-93

Gage JD, Tyler PA (1981) Non-viable seasonal settlement of larvae of the upper bathyal brittlestar Ophiocten gracilis in the Rockall Trough abyssal. Mar Biol 64:153-161

Gage JD, May RM (1994) A dip into the deep seas. Nature 365:609-610

Gage JD, Tyler PA (1991) Deep-sea biology: a natural history of organisms at the deep-sea floor. Cambridge University Press, Cambridge

Gerlach SA, Hahn AE, Schrage M (1985) Size spectra of benthic biomass and metabolism. Mar Ecol Prog Ser 26: 161-173

Gooday AJ (1988) A response by benthic Foraminifera to the deposition of phytodetritus in the deep sea. Nature 332: $70-73$

Grassle JF, Maciolek NJ (1992) Deep-sea species richness: regional and local diversity estimates from quantitative bottom samples. Am Nat 139:313-341

Grassle JF, Grassle JP, Brown-Leger LS, Petereca RF, Coplely NJ (1985) Subtidal macrobenthos of Narragansett Bay: field and mesocosm studies of the effects of eutrophication and organic input on benthic populations. In: Gray JE, Christiansen ME (eds) Marine biology of polar regions and effects of stress on marine organisms. John Wiley, Chichester, $\mathrm{p}$ 421-434

Grassle JF, Sanders HL (1973) Life histories and the role of disturbance. Deep-Sea Res 20:643-659

Gray J (1989) Effects of environmental stress on species rich assemblages. Biol J Linn Soc 37:19-32

Gray JS, Mirza FB (1979) A possible method for detecting pollution-induced disturbance on marine benthic communities. Mar Pollut Bull 10:142-146

Gray JS, Clarke KR, Warwick RM, Hobbs G (1990) Detection of initial effects of pollution on marine benthos: an example from the Ekofisk and Eldfisk oilfields, North Sea. Mar Ecol Prog Ser 66:185-299

Hessler RR (1974) The structure of deep benthic comunities from central oceanic waters. In: Miller CB (ed) The biology of the oceanic Pacific. Oregon State University Press, Corvallis, p 79-93

Hessler RR, Jumars PA (1974) Abyssal community analysis from replicate box cores in the central North Pacific. Deep-Sea Res 21:185-209

Hill MO (1973) Diversity and evenness: a unifying notation and its consequences. Ecology 54:427-432

Hurlbert SH (1971) The non-concept of species diversity: a critique and alternative parameters. Ecology 52:577-586

Jumars PA, Gallagher ED (1982) Deep-sea community structure: three plays on the benthic proscenium. In: Ernst WG, Morin JG (eds) The environment of the deep sea. PrenticeHall, Englewood Cliffs, NJ, p 217-255

Lambshead PJD, Platt HM, Shaw KM (1983) The detection of differences among assemblages of marine benthic species based on an assessment of dominance and diversity. J Nat Hist 17:859-874

Maciolek NJ, Grassle JF, Hecker B, Boehm PD and 6 others (1987a) Study of biological processes on the US midAtlantic slope and rise: final report prepared for US Department of the Interior, Minerals Management Service, Washington, DC

Maciolek NJ, Grassle JF, Hecker B, Brown B and 6 others (1987b) Study of biological processes on the U.S. North Atlantic slope and rise: final report prepared for US De- partment of the Interior, Minerals Management Service, Washington, DC

Magurran A (1988) Ecological diversity and its measurement. Chapman and Hall, London

Mare MF (1942) A study of a marine benthic community with special reference to the micro-organisms. J Mar Biol Assoc UK 25:517-554

Olsgard F, Somerfield PJ, Carr MR (1998) Relationships between taxonomic resolution, macrobenthic community patterns and disturbance. Mar Ecol Prog Ser 172:25-36

Pearson TH, Rosenberg R (1978) Macrobenthic succession in relation to organic enrichment and pollution of the marine environment. Oceanogr Mar Biol Annu Rev 16:229-311

Platt HM, Shaw KM, Lambshead PJD (1984) Nematode species abundance patterns and their use in the detection of environmental perturbations. Hydrobiologia 118:59-66

Rees HL (1984) A note on mesh selection and sampling efficiency in benthic studies. Mar Pollut Bull 15:225-229

Reish DJ (1959) A discussion of the importance of screen size in washing quantitative marine bottom samples. Ecology 4:307-309

Rex MA, Etter RJ (1998) Bathymetric patterns of body size: implications for deep-sea biodiversity. Deep-Sea Res Part II Top Stud Oceanogr 45:103-127

Rowe GT (1983) Biomass and production of the deep-sea macrobenthos. In: Rowe GT (eds) The sea, Vol. 8. WileyInterscience, New York, p 97-121

Rowe GT, Menzel DW (1971) Quantitative benthic samples from the deep Gulf of Mexico with comments on the measurement of deep-sea biomass. Bull Mar Sci 21:556-566

Sanders HL (1968) Marine benthic diversity: a comparative study. Am Nat 102:243-282

Sanders HL, Hessler RR, Hampson GR (1965) An introduction to the study of the deep-sea benthic faunal assemblages along the Gay Head-Bermuda transect. Deep-Sea Res 12: 845-867

Schwinghamer P (1981) Characteristic size distribution of integral benthic communities. Can J Fish Aquat Sci 38: 1255-1263

Schwinghamer P (1983) Generating ecological hypotheses from biomass spectra using causal analysis: a benthic example. Mar Ecol Prog Ser 13:151-166

Schwinghamer P (1985) Observations on size structure and pelagic coupling of some shelf and abyssal benthic communities. In: Gibbs PE (ed) Proceedings of the nineteenth European Marine Biology Symposium. Cambridge University Press, Cambridge, p 347-359

SCOR Working Group 76 (1994) Suggested criteria for describing deep-sea benthic communities; the final report of SCOR Working Group 76. Prog Oceanogr 34:81-100

Shaw KM, Lambshead PJD, Platt, HM (1983) Detection of pollution induced disturbance in marine benthic asseblages with special reference to nematodes. Mar Ecol Prog Ser 11:195-202

Soetaert K, Heip C (1990) Sample-size dependence of diversity indices and the determination of sufficient sample size in a high-diversity deep-sea environment. Mar Ecol Prog Ser 59:305-307

Thiel H (1975) The size structure of the deep-sea benthos. Int Rev Gesamten Hydrobiol 60:575-606

Thiel H (1983) Meiobenthos and nanobenthos of the deep sea. In: Rowe GT (ed) The sea, Vol. 8. Wiley-Interscience, New York, p 167-230

Thistle D, Yingst JY, Fauchald K (1985) A deep-sea benthic community exposed to strong bottom currents on the Scotian Rise (Western Atlantic). Mar Geol 6:91-112

Thorson G (1946) Reproduction and larval development of 
Danish marine bottom invertebrates. Medd Kom Dan Fisk Havunders Plankton 4:1-523

Thorson G (1966) Some factors influencing the recruitment and establishment of marine benthic communities. Neth J Sea Res 3:267-293

Tyler PA (1988) Seasonality in the deep sea. Oceanogr Mar Biol Annu Rev 26:227-258

Ugland KI, Gray JS (1982) Lognormal distributions and the concept of community equilibrium. Oikos 39:171-178

Vitellio P, Dinet A (1979) Définition et échantillonage du

Editorial responsibility: Otto Kinne (Editor),

Oldendorf/Luhe, Germany meiobenthos. Rapp P-V Reun Comm Int Explor Sci Mer Méditerr Monacao 25/26:279-283

Warwick RM (1984) Species size distributions in marine benthic communities. Oecologia 61:32-41

Warwick RM, (1987) The size distribution of organisms in the Celtic Sea: from bacteria to Metazoa. Oecologia 73:185-191

Warwick RM, Clark, KR (1996) Relationships between bodysize, species abundance and diversity in marine benthic assemblages: facts or artefacts? J Exp Mar Biol Ecol 202: $63-71$

Submitted: October 23, 2000; Accepted: March 15, 2001 Proofs received from author(s): January 9, 2002 